P-ISSN 2580 - 7781

E-ISSN $2615-3238$

\title{
JURNALISME INDEPENDEN MEDIA TELEVISI : ANALISIS FRAMING TAYANGAN PROGRAM MATA NAJWA EPISODE "MEREKA-REKA CIPTA KERJA" DI TRANS7
}

\author{
INDEPENDENT JOURNALISM TELEVISION MEDIA : FRAMING \\ ANALYSIS OF MATA NAJWA'S PROGRAM SHOW"MEREKA-REKA \\ CIPTA KERJA" ON TRANS7
}

\author{
Anisa Salma Febriana ${ }^{1)}$, Firdaus Yuni Dharta ${ }^{2)}$, Oky Oxcygentri ${ }^{3)}$ \\ 1,2.3Jurusan Ilmu Komunikasi, Fakultas Ilmu Sosial Ilmu Politik, Universitas \\ Singaperbangsa Karawang \\ 1Email: contact.anisasf@gmail.com
}

\begin{abstract}
ABSTRAK
Media adalah sarana untuk menyampaikan informasi, namun pada hakikatnya sebuah informasi adalah pesan yang dapat membentuk makna dan latarbelakang dari sebuah tindakan publik. Penelitian ini di latarbelakangi atas pergolakan aksi penolakan yang terjadi pada tahun 2020 sebagai dampak pemberitaan media dari kebijakan Ominibuslaw, RUU Cipta Kerja yang disahkan secara resmi menjadi Undang-Undang melalui Rapat Paripurna pada tanggal lima Oktober 2020 oleh DPR. Tujuan dari penelitian ini adalah untuk mengetahui pembingkaian dalam program Mata Najwa. Apakah tayangan program Mata Najwa ini layak dijadikan sebagai sumber informasi yang akurat dan menerapkan prinsip jurnalisme independen. Penelitian ini menggunakan metode kualitatif, data dikumpulkan berupa video dokumentasi dan di transkrip kemudian dianalisa menggunakan analisis framing model Robert N. Entmen. Hasil penelitian ini menunjukan bahwa adanya keseimbangan dalam pemilihan narasumber antara yang pro dan kontra terhadap kebijakan Omnibuslaw, namun tidak adanya penyelesaian dalam tayangan tersebut, hanya klarifikasi dari sebuah kebijakan dan pendapat dari kebijakan tersebut, ketidakseimbangan pemberitaan juga terdapat pada tayangan ini dengan porsi pro sedikit lebih besar. tayangan program Mata Najwa Episode "Mereka-Reka Cipta Kerja" Di Trans7 dapat menjadi sumber informasi yang akurat dan menerapkan prinsip jurnalisme independen.
\end{abstract}

Kata kunci:Analisis framing, Robert n. entmen, Jurnalisme independen

\begin{abstract}
Media is a means to convey information, but in essence an information is a message that can shape the meaning and background of a public action. This research is motivated by the upheaval of the rejection action that occurred in 2020 as a result of media coverage of the Ominibuslaw policy, the Job Creation Bill which was officially passed into law through a Plenary Meeting on October 5, 2020 by the DPR. The purpose of this study is to determine the framing in the program Mata Najwa. Is this Mata Najwa program worthy of being used as a source of accurate information and applying the principles of independent journalism. This study used a qualitative method, the data was collected in the form of video documentation and transcribed and then analyzed using Robert $N$. Entmen's framing analysis model. The results of this study indicate that there is a balance in the selection of sources between the pros and cons of the Omnibuslaw policy, but there is no resolution in the show, only a clarification of a policy and the opinion of the policy, the imbalance of news is also found in this show with a slightly more pro portion big. The
\end{abstract}


P-ISSN 2580 - 7781

E-ISSN $2615-3238$

Mata Najwa Episode program "Mereka-Reka Cipta Kerja" on Trans7 can be a source of accurate information and apply the principles of independent journalism.

Keywords:Framing analysis, Robert $n$. entmen, Independent journalism

\section{PENDAHULUAN}

Dalam konteks sosiologi, perubahan sikap sosial dipengaruhi oleh informasi baru yang diterimanya, yang berkaitan dengan kebutuhan bersyarat: kapan dan di mana informasi baru diterima. Lambat laun, dan tanpa disadari atau tidak, perubahan mulai terjadi, di satu sisi, besarnya perubahan tergantung pada intensitas efek media sebagai saluran. Berita sebagai media informasi merupakan kekuatan yang dapat mempengaruhi dan mengubah perilaku masyarakat.

Pers selalu menyajikan informasi terbaru sesuai dengan salah satu unsurnya yaitu kebaruan (aktualitas), selain informasi juga mengandung ide-ide atau opini yang di anggap relevan dengan apa yang di beritakan. Pers mempunyai kekuatan yang sangat besar untuk mengendalikan masa karena daya persuasinya yang kuat dalam membentuk opini publik.

Pada era yang semakin di kuasai oleh teknologi sehingga mudahnya masyarakat untuk mangakses segala berita dan informasi. Hal inilah yang menjadi penyebab konflik besar terjadi pada masyarakat Indonesia karena bebasnya informasi yang beredar dan kurangnya menganalisis kebenaran dari sebuah informasi, salah satu isu yang menjadi konflik besar di Indonesia pada tahun 2020 adalah Omnibuslaw RUU Cipta Kerja yang santer di beritakan oleh media, banyak sekali pro kontra karena kebijakan ini menyangkut hidup masyarakat Indonesia dan terdapat banyak kepentingan didalam RUU Cipta Kerja, kepentingan masyarakat, pengusaha/investor dan pemerintah. Omnibuslaw merupakan "konsep baru yang digunakan dalam sistem perundang-undangan Indonesia." Sistem tersebut sering disebut sebagai "Universal Sweep Law" karena mampu "mengkonsolidasikan berbagai peraturan perundang-undangan menjadi satu peraturan". Hukum komprehensif, beberapa undang-undang akan disederhanakan, disinkronkan, dan direvisi.

Pada awal tahun 2020, pemerintah sedang menyiapkan rancangan undangundang (selanjutnya disebut RUU) yang menggunakan konsep Omnibuslaw. Pemerintah sedang mempersiapkan RUU tersebut sebagai rencana untuk 
membangun perekonomian Indonesia agar mampu menarik investor untuk menanamkan modalnya di Indonesia. Karena angka pengangguran di Indonesia mencapai 7 juta, pemerintah berpendapat RUU penciptaan lapangan kerja ini perlu dirumuskan, sehingga diharapkan RUU tersebut dapat membuka lapangan kerja baru. Sejak awal pembahasan Omnibuslaw ini mendapat perhatian dari masyarakat karena adanya beberapa peraturan yang di sebut hanya menguntungkan beberapa pihak dan mengesampingkan kepentingan rakyat, pro kontra terus terjadi selama pembahasan RUU. Pembahasan Omnibuslaw Klaster ketenagakerjaan sempat ditunda karena banyak pro kontra dalam naskah RUU dan di anggap tidak etis karena adanya pembahasan kebijakan yang sangat besar menyangkut masyarakat luas, di tengah pandemi Covid-19 dengan segala pembatasan ruang gerak, resmi di tunda dan di sampaikan oleh Presiden Jokowi melalui akun youtube Sekretariat Presiden pada 24 April 2020,'Klaster ketenagakerjaan pembahasannya resmi ditunda, ini sesuai dengan keinginan pemerintah, hal ini juga untuk memberikan kesempatan kepada kita untuk mendalami lagi substansi dari pasal-pasal terkait dan mendapatkan masukan dari para pemangku kepentingan," ujar Presiden Joko Widodo. Kemudian DPR RI diberitakan kembali menjadwalkan pembahasan RUU Cipta Kerja setelah pembukaan masa sidang IV pada tahun 2019-2020, pada Senin 16 Juni 2020 direncanakan sepuluh kali rapat untuk membahas RUU Cipta kerja dalam jangka waktu 15 Juni-17 Juli 2020. Setelah beberapa agenda sidang terlaksana pada tanggal lima Oktober 2020 DPR mengesahkan Ominibuslaw RUU Cipta Kerja secara resmi menjadi Undang-Undang melalui Rapat Paripurna.

Setelah pengesahan UU ini banyak sekali isu dan pemberitaan beredar di masyarakat, di tengah masih adanya pergolakan antara pro kontra, kondisi pandemi Covid-19, pembahasan dan pengesahan yang di anggap kilat, tertutup dan hanya mementingkan kepentingan oligarki. Pemerintah di anggap tidak etis melakukan pengesahan di tengah pandemi Covid-19 yang di anggap memanfaatkan momen di tengah pembatasan pergerakan untuk mengesahkan sebuah kebijakan, tak hanya itu proses persidangan dianggap kontroversional dan terburu-buru, beberapa kejadian didalam persidangan yang menjadi marak di 
perbincangkan dan mendapat perhatian publik adalah tindakan dari ketua DPR RI Puan Maharani yang di anggap mematikan microphone salah satu dewan yang berinterupsi untuk menyanggah/berpendapat dan beberapa aksi dewan memilih walkout dari persidangan karena kebijakan pengesahan RUU Cipta Kerja ini. Kebijakan pengesahaan ini mendapat respon yang sangat luas dari masyarakat Indonesia, karena informasi dapat di akses secara cepat dan banyaknya informasi yang kurang tepat, terjadinya pembingkaian informasi/berita mengenai pengesahan UU ini, banyak sekali perspektif yang berkembang di masyarakat mengenai pemberitaan ini, pemberitaan negatif membuat perspektif masyarakat menjadi negatif sehingga menimbulkan pergolakan penolakan pengesahan UU Cipta Kerja ini karena di anggap merugikan masyarkat khusunya para buruh. Penolakan gencar di lakukan tak hanya kaum buruh, tetapi mahasiswa, aktivis, pelajar dan masyarakat luas ikut andil dalam penolakan UU ini.Pergolakan terjadi di jalanan, jutaan orang menuntut keadilan atas kebijakan yang sudah disahkan, hal ini tentu sangat berbahaya untuk stabilitas negara, perpecahan rawan terjadi di tengah pemberitaan yang bebas tersebar melalu media, informasi yang bebas beredar memberikan dampak yang besar terhadap pergerakan publik. Oleh karena itu, pemilihan sumber informasi dan media merupakan hal penting agar kita tidak salah dalam memaknai sebuah isu, penerapan jurnalisme independen harusnya di terapkan oleh seluruh media agar terciptanya media yang terpercaya dan terjaganya stabilitas negara.

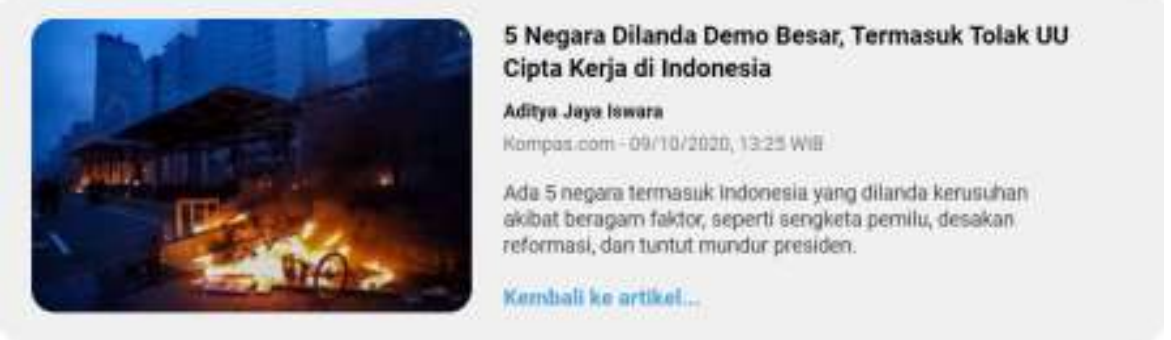

Gambar 1. 5 Negara yang Dilanda Demo Besar tahun 2020

Sumber: Kompas.com

Terciptanya media yang dapat di percaya oleh masyarakat, haruslah setiap media dapat menjunjung tinggi nilai independensi dan objektivitasnya. 
Kewartawanan atau jurnalisme adalah kegiatan menghimpun berita, mencari fakta, dan melaporkan peristiwa. Konsep berita dalam konsep media berasal dari kata "journal", yang berarti catatan harian tentang kejadian sehari-hari atau surat kabar. Jurnal berasal dari bahasa latin diurnalis yang berarti setiap hari atau setiap hari.

Jurnalisme memiliki tanggung jawab untuk menyampaikan kebenaran, setia kepada masyarakat, memiliki disiplin untuk memverifikasi, independensi dalam peliputannya, memiliki kemampuan untuk mengawasi kekuasaan, menjadi wadah kritik dan persetujuan publik, serta menyampaikan dengan menarik dan relevan, diproduksi secara penuh komprehesif dan proporsional, memungkinkan jurnalis untuk mengikuti hati nurani mereka dengan bebas.

Menurut media yang digunakan, berita biasanya dibagi menjadi berita cetak, berita elektronik dan berita online. Jurnalisme independen adalah prinsip penerapan jurnalis. Berikut adalah pandangan penerapan prinsip jurnalisme independen dan jurnalisme partisan, perbedaannya adalah:

1. Jurnalisme independen Ini adalah aktivitas berita dan tidak akan memelihara kontak dengan kelompok atau kelompok tertentu dalam proses pelaporan dan penulisan berita. Pemberitaan media seringkali mencakup dua aspek (dua aspek) dan mengakomodasi pernyataan dua kelompok yang berbeda. Dengan cara ini orang bisa mendapatkan informasi yang benar tanpa dibimbing untuk membentuk emosi tertentu.

2. Jurnalisme partisan Di sisi lain, Dalam praktiknya, ia lebih mengutamakan kepentingan kelompok yang dibelanya, ketimbang berdasarkan konsep berita berdasarkan fakta dan makna. Pada jurnalisme partisan, kesalahan sekecil apa pun dari kelompok pembangkang akan dilaporkan secara berlebihan. Pada saat yang sama, kesalahan besar dalam grup akan ditutup-tutupi. Dengan cara ini, emosi tertentu akan muncul dan dapat memicu konflik.

Berita independen adalah pandangan dan prinsip bahwa kita tidak terikat pada pihak manapun, artinya fakta kita bersifat independen dan tidak sesuai dengan kepentingan pihak atau organisasi tertentu. Jurnalisme independen 
memang belum banyak dikaji secara mendalam, namun prinsip jurnalisme independen menjadi populer di beberapa webinar dan pelatihan tentang jurnalis.

Menjadi jurnalis independen adalah harapan semua jurnalis agar iklim di media membaik dan kepercayaan masyarakat terhadap media dapat kembali, masyarakat juga mengharapkan agar para jurnalis menjadi jurnalis yang independen dan berorientasi pada kebenaran dan tidak memihak.

Tujuan dari penelitian ini adalah untuk mengetahui pembingkaian dalam program Mata Najwa. Apakah tayangan program Mata Najwa ini layak dijadikan sebagai sumber informasi yang akurat dan menerapkan prinsip jurnalisme independen.

\section{METODE PENELITIAN}

Metode penelitian kualitatif yang digunakan dalam penelitian ini. Penelitian kualitatif menekankan pada proses dan makna dari realitas sosial, daripada mengukurnya berdasarkan kuantitas atau frekuensi.

Fokus penelitian kualitatif adalah menjelaskan bagaimana fenomena sosial terbentuk dan memberi makna. Penelitian kualitatif merupakan fokus dari berbagai metode, dalam metode ini penelitian bertujuan untuk memahami atau menjelaskan fenomena dari perspektif makna yang peneliti nilai.

Dalam penelitian kualitatif, subjek penelitiannya adalah siapa pemberi informasi atau sumber informasi. Orang dalam penelitian adalah subjek yang memahami informasi objek penelitian sebagai aktor dan orang lain yang memahami objek penelitian, peneliti hanya sebagai subjek media yang ingin memahami informasi objek penelitian, peneliti hanya satu subjek media yang ingin di teliti yaitu program Mata Najwa sebagai program acara televisi yang menjadi sumber penelitian. Objek penelitian merupakan fokus pertanyaan, dan selanjutnya akan dianalisis untuk menjawab rumusan pertanyaan penelitian. Oleh karena itu, objek penelitian ini adalah adalah pembingkaian (framing) yang dilakukan Najwa Shihab sebagai moderator atau pengendali pada tanyangan program acara Mata Najwa yang berlangsung secara live. 


\section{P-ISSN $2580-7781$}

E-ISSN $2615-3238$

Peneliti memilih program tayangan tersebut karena Mata Najwa di Trans7 meraih nilai indeks tertinggi 3,64 dari standar KPI. Data sekunder berupa artikel, literatur maupun buku-buku yang terdapat kaitannya dengan penelitian Teknik pada pengumpulan data yang digunakan pada penelitian ini adalah observasi, dokumentasi dan studi pustaka. Teknik analisis penelitian ini menggunakan analisi framing model kerangka kerja Robert N. Entman.

\section{HASIL PENELITIAN DAN PEMBAHASAN}

Analisis framing merupakan analisis memperhatikan pada bagian media melakukan pengemasan dan pembingkaian berita. Proses itu sering dilakukan dengan menentukan peristiwa yang dipilih dalam pemberitaan dan dilakukan penekanan pada aspek tertentu pada gambar, aksentuasi kalimat, kata dan bagian lainnya. Model analisis kerangka kerja Robert N. Entman digunakan untuk penelitian ini. Pilihan model analisis bingkai Model Robert N. Entman menekankan pada analisis dua dimensi sebagai alat. Pertama-tama, pilihan pertanyaan. Proses pemilihan dari berbagai realitas untuk membuat bagian-bagian tertentu dari acara menonjol dari keramaian. Entman juga memasukkan informasi dalam konteks tertentu sehingga aspek-aspek tertentu dapat memperoleh bagian yang lebih besar daripada yang lain. Aspek ini menyangkut bagaimana media memilih fakta pada kenyataan politik yang kompleks dan bermacam-macam, selanjutnya menyajikan atau melaporkannya untuk publik, ada berita yang disertakan di sini, dan berita yang telah dibuang atau dirilis. Kemudian, tidak semua berita ditunjukan ke publik.

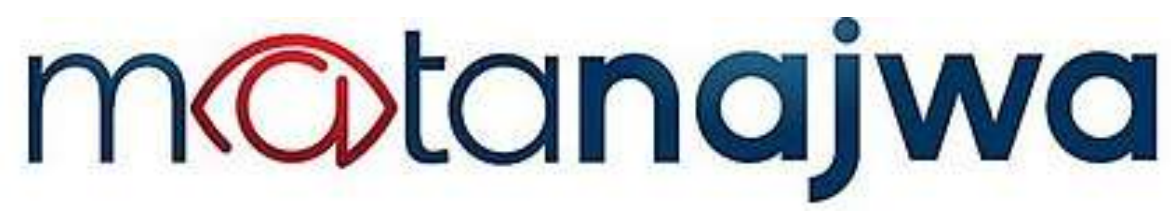

Gambar 2. Logo Mata Najwa

Sumber: https://www.narasi.tv/mata-najwa

Penelitian ini akan menganalisis tayangan Mata Najwa episode "MerekaReka Cipta Kerja", Mata Najwa merupakan program talkshow yang dipandu oleh 
Najwa Shihab, seorang jurnalis dengan pemilik karakter berani, lugas, cerdas serta berkarisma kuat.

Awalnya, program Mata Najwa merupakan program in depth talkshow unggulan yang tayang di Metro TV, setelah mengundurkan diri dari Metro TV, Najwa membentuk Narasi TV, sebuah media baru berbasis digital. Tiga bulan setelahnya, Narasi TV bekerja sama dengan TRANS 7 sehingga Mata Najwa dapat hadir kembali di layar kaca televisi, menjadi sebuah program talkshow berita di TRANS7 setiap Rabu pukul 20.00 dan berdurasi dua jam. Selain itu, Mata Najwa juga dapat disaksikan di website www.narasi.tv dan kanal youtube Najwa Shihab.

Program ini telah meraih beberapa penghargaan di dalam maupun di luar negeri, yakni berhasil menjadi nominasi talkshow terbaik seAsia Pasifik dalam ajang Asian Television Awards 2010, talkshow terbaik Dompet Dhuafa Awards 2011, dan pada 2011- 2012 berhasil masuk tiga besar talkshow yang paling banyak dibicarakan versi SWA Magazine.

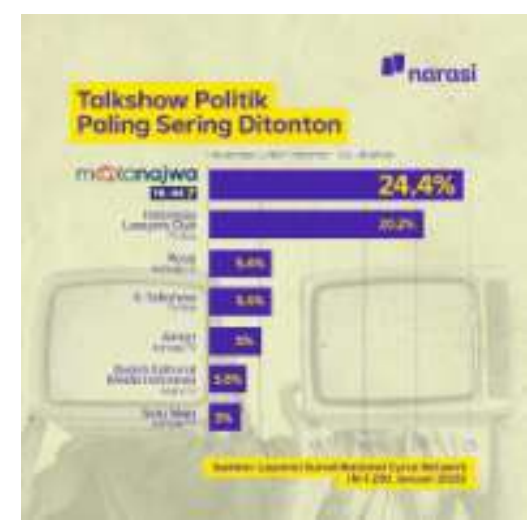

Gambar 3. Hasil Survei Talkshow Politik Paling Sering di Tonton tahun 2020 Sumber: Cyrus Network

Berdasarkan hasil survei diatas, talkshow politik paling sering di tonton menurut laporan survei nasional oleh Cyrus Network, yang melibatkan 1.230 responden yang tersebar pada 123 desa/kelurahan terpilih di 34 provinsi di Indonesia, Mata Najwa menduduki posisi pertama dengan 24,4\%, kemudian Indonesia Lawyers Club 20,2\%, Rossi 5,4\%, E-Talkshow 5,4\%, Aiman 5\%, Bedah Editorial Media Indonesia 3,8\% dan Satu Meja $3 \%$. 
Berdasarkan pemikiran peneliti dan ditunjang dengan hasil survei ini bahwa program Mata Najwa adalah program talkshow paling populer di Indonesia dan paling banyak di tonton, maka tayangan pada program Mata Najwa mempunyai dampak yang dahsyat untuk masyarakat.

Dalam penelitian ini digunakan analisis framing model Robert N. Entman untuk menjelaskan bagaimana Mata Najwa membingkai realitas dari permasalahan pro kontra pengesahan Omnibuslaw UU Cipta kerja oleh DPR.

Menurut Entman framing dibagi kedalam dua aspek utama adalah pilihan masalah dan penonjolan realitas atau aspek-aspek tertentu dari masalah. Pemilihan masalah merupakan aspek yang berkaitan dengan pemilihan berbagai fakta dan realitas yang dilakukan melalui empat strategi media atau elemen utama, yaitu mendefinisikan masalah, memperkirakan sumber masalah, membuat keputusan etis,dan menekankan/menyelesaikan masalah. aspek isi yang menonjol adalah aspek yang berkaitan dengan fakta penulisan.

Pada penelitian ini peneliti hanya menekankan pada satu elemen dari Robert N. Entman yaitu bagaimana menekankan/penyelesaian isu yang dilakukan pada program Mata Najwa episode "Mereka-Reka Cipta Kerja” di Trans7.

1. Berdasarkan seleksi isu

Seleksi isu dan penonjolan aspek tertentu dari isu merupakan tahap untuk menemukan bingkai (frame) yang di bentuk oleh Mata Najwa dalam menyampaikan informasi terkait permasalahan pro kontra kebijakan Omnibuslaw UU Cipta Kerja. Treatment Recommendation (menekankan penyelesaian) dalam penyelesaian permasalahan mengenai pengesahan Omnibuslaw UU Cipta Kerja. Mata Najwa menilai adanya kesalahan dari pemerintah khusunya DPR karena draft UU Cipta Kerja ini masih belum di bagikan bahkan kepada anggota Baleg sendiri. Pernyataan tersebut bisa kita lihat dari pernyataan anggota Baleg Ledia Hanifah, yang kemudian di sampaikan dan ditegaskan kembali oleh Najwa Shihab selaku moderator.

Judul Segmen 1 : Mereka-Reka Cipta Kerja: Di Balik Kejar Tayang UU Cipta Kerja (Part 1) 1 Mata Najwa

Jumlah Penonton : 5,425,480 Penonton (8 Oktober 2020-30 Mei 2021) 
P-ISSN 2580 - 7781

E-ISSN 2615 - 3238

\begin{tabular}{|c|c|c|c|}
\hline No & Pengisi & Isi & Waktu \\
\hline 8. & $\begin{array}{l}\text { Najwa } \\
\text { Shihab }\end{array}$ & $\begin{array}{l}\text { Terimakasih sudah bergabung di Mata Najwa ee ada banyak } \\
\text { hal yang ingin saya bahas malam ini dan memang ee dan } \\
\text { sengaja mengundang tiga lawan tiga karena saya tahu yang } \\
\text { tiga tentunya Pro atau yang terlibat langsung dalam undang } \\
\text { dan yang tiga yang kerap kali menyuarakan penolakan nya ee } \\
\text { saya ingin membahas sebelum masuk substansi Saya ingin } \\
\text { membahas soal proses prosedur awal mula bagaimana } \\
\text { kemudian undang-undang ini disorot publik saya ingin mulai } \\
\text { ke bu Ledia, bu Ledia yang jelas dinilai tidak terbuka, cepat, } \\
\text { kilat, dadakan, anda kan mengalami dan mengamati langsung, } \\
\text { terlibat langsung apakah penilaian itu tepat. }\end{array}$ & $02.58-03.39$ \\
\hline 9. & $\begin{array}{l}\text { Ledia } \\
\text { Hanifah }\end{array}$ & $\begin{array}{l}\text { Ya memang beberapa hal memang betul sangat cepat, karena } \\
\text { juga kalau menurut kami ya ada beberapa hal yang e masih } \\
\text { kurang untuk di pahami ee yaitu mengambil masukan- } \\
\text { masukan dari masyarakat secara umum, pakar dan lain } \\
\text { Sebagian, sudah di lakukukan tapi masih kurang banyak } \\
\text { karena ee itu yang ee sangat penting ya krusial, karenanya di } \\
\text { masa resis lalu kami tidak ikut pembahasan Omnibuslaw ini } \\
\text { karena kami ingin mengambil banyak e masukan dari } \\
\text { masyarakat dalam hal ini konstituen kami, karena apa karna } \\
\text { resis tujuannya tugasnya adalah untuk mengambil aspirasi dari } \\
\text { masyarakat secara umum. Jadi ini persoalan yang sangat } \\
\text { penting karena memang kemudian mengatur, mengelola } 79 \\
\text { undang-undang ini gak gampang Mba Nana karena ada } \\
\text { banyak hal yang harus terkait satu sama lain sinergi dan lain } \\
\text { sebagainya, menjadi kesulitan yang besar bagi kita semua } \\
\text { karena misalnya ee kita di dalam rapat pembahasan tingkat } \\
\text { satu pengambilan keputusan juga belum ada draft isinya pada } \\
\text { saat sebelum e membuat pandangan ini di fraksi, jadi saya } \\
\text { khawatir sebenernya hoaks itu ada banyak sekali dikarena } \\
\text { memang tidak pada megang draftnya itu. }\end{array}$ & $03.39-04.52$ \\
\hline 10 & $\begin{array}{l}\text { Najwa } \\
\text { Shihab }\end{array}$ & Anda sampai sekarang belum pegang draftnya juga bu? & $04.52-04.56$ \\
\hline 11 & $\begin{array}{l}\text { Ledia } \\
\text { Hanifah }\end{array}$ & Saya sampai tadi siang sudah minta tapi belum dapat & $04.52-05.00$ \\
\hline 12 & $\begin{array}{l}\text { Najwa } \\
\text { Shihab }\end{array}$ & $\begin{array}{l}\text { Bahkan anggota DPR, anggota Baleg belum dapat } \\
\text { draftnya? }\end{array}$ & $05.00-05.03$ \\
\hline 13 & $\begin{array}{l}\text { Ledia } \\
\text { Hanifah }\end{array}$ & $\begin{array}{l}\text { Ee karena, katanya, masih masih diatur ee di rapihkan hal-hal } \\
\text { yang teknisnya, ee apa menyerap hal yang teknisnya }\end{array}$ & 05.03-05.14 \\
\hline 14 & $\begin{array}{l}\text { Najwa } \\
\text { Shihab }\end{array}$ & $\begin{array}{l}\text { Baik karena kami juga meminta dan belum dapat, tadinya saya } \\
\text { waa karena media belum dapat tapi bahkan anggota Balegnya } \\
\text { sendiri juga belum dapat maka ee itu perlu di jawab nanti, } \\
\text { tapi sebelum sebelum di jawab oleh ketua Baleg saya ingin ke } \\
\text { bang Hariz Azhar. Ee bang Hariz anda anda menyebut } \\
\text { Undang-Undang Cipta Kerja kecurangan Legislatif, kenapa } \\
\text { anda sampai memakai kata itu Kecurangan Legislatif? }\end{array}$ & $05.14-05.36$ \\
\hline
\end{tabular}


P-ISSN 2580 - 7781

E-ISSN 2615 - 3238

Selain itu, diakhir talkshow tersebut penyelesaian yang dilakukan oleh Mata Najwa adalah menarik komitmen dari ketua Baleg Supratman Andi Atgas tentang kepeduliannya terhadap suara-suara publik. Banyak sekali suara rakyat yang tersebar di media maupun di jalanan, diharapkan dengan penyelesain isu yang dilakukan oleh Mata Najwa dapat menjadi komitmen untuk ketua Baleg mempertimbangkan Kembali dan mendengar suara rakyat dengan memperbanyak konsultasi publik sebelum mengesahkan kebijakan untuk di patuhi oleh publik, karena Undang-Undang pada hakikatnya adalah dari rakyat dan untuk rakyat.

Judul Segmen 7: Mereka-Reka Cipta Kerja: UU Cipta Kerja Disahkan, Kita Bisa Apa? (part 7) 1 Mata Najwa

Jumlah Tayangan: 1,024,595 penonton (8 Oktober 2020-30 Mei 2021)

\begin{tabular}{|c|c|c|c|}
\hline $\mathrm{No}$ & Pengisi & Isi & Waktu \\
\hline 8. & $\begin{array}{l}\text { Najwa } \\
\text { Shihab }\end{array}$ & $\begin{array}{l}\text { Bang Supratman pertanyaan saya terakhir apakah } \\
\text { DPR masih peduli dengan berbagai penilaian dan } \\
\text { persepsi buruk rakyat terhadap wakilnya ada yang } \\
\text { sudah semakin kencang suara-suara mosi tidak } \\
\text { percaya anda dituduh bersalah }\end{array}$ & $03.25-03.37$ \\
\hline 9. & $\begin{array}{l}\text { Supratman } \\
\text { Andi Atgas }\end{array}$ & $\begin{array}{l}\text { Saya yakin dan percaya bahwa sejarah akan membuktikan } \\
\text { bahwa apa yang kita lahirkan hari ini lewat Omnibuslaw } \\
\text { itu akan membuat titik tonggak baru bagi dalam perjalanan } \\
\text { kehidupan }\end{array}$ & $03.37-03.47$ \\
\hline 10. & $\begin{array}{l}\text { Najwa } \\
\text { Shihab }\end{array}$ & $\begin{array}{l}\text { Bapak Supratman yang terhormat apakah anda masih } \\
\text { peduli dengan suara-suara publik, apakah masih } \\
\text { peduli dengan suara publik? }\end{array}$ & $03.47-03.55$ \\
\hline 11. & $\begin{array}{l}\text { Supratman } \\
\text { Andi Atgas }\end{array}$ & Pasti pasti kita & $03.55-03.59$ \\
\hline 12. & $\begin{array}{l}\text { Nahwa } \\
\text { Shihab }\end{array}$ & $\begin{array}{l}\text { Kita akan lihat, Terima kasih banyak sudah bergabung di } \\
\text { Mata Najwa malam ini Bapak Bapak Terima kasih kepala } \\
\text { BKPM Bahlil Lahadalia, Ketua Badan Legislasi DPR } \\
\text { Supratman Andi Ttgas, Ketua Apindo Hariyadi } \\
\text { Sukamdani, Direktur Eksekutif Lokataru Haris Azhar } \\
\text { Ekonomi Faisal Basri dan anggota baleg DPR fraksi PKS } \\
\text { Ledia Hanifa Amalia sengaja kami undang } 3 \text { masing- } \\
\text { masing pro kontra tentunya masih jauh dari selesai } \\
\text { perbincangan ini mudah-mudahan kita akan bisa } \\
\text { berdiskusi di lain kesempatan tetapi Mata Najwa Selamat } \\
\text { malam terima kasih teman-teman Sehat terus semuanya } \\
\text { sampai jumpa }\end{array}$ & $03.59-04.30$ \\
\hline
\end{tabular}


2. Prinsip Penerapan Jurnalisme Independen

Program Mata Najwa pada episode "Mereka-Reka Cipta Kerja" di Trans7 menunjukan bahwa adanya keseimbangan dalam pemilihan narasumber antara yang pro dan kontra terhadap kebijakan Omnibuslaw, dari keleluasaan berbicara Mata Najwa juga tidak membatasi narasumber untuk berbicara dan talkshow tersebut dapat di akses secara terbuka di televisi maupun youtube kemudian untuk hasil dari diskusi tersebut juga di bagikan ke dalam kanal youtube NarasiTV dan Najwa Shihab. Tayangan program Mata Najwa Episode “Mereka-Reka Cipta Kerja” Di Trans7 dapat menjadi sumber informasi yang akurat dan menerapkan prinsip jurnalisme independent atau tidak memihak dan sangat terbuka.

\section{KESIMPULAN}

Berdasarkan analisi framing model Robert N. Entman pada program tayangan Mata Najwa episode "Mereka-Rera Cipta Kerja" di Trans7, maka diperoleh kesimpulan bahwa pembingkaian dalam episode ini menggambarkan mengenai sikap DPR yang kurang terbuka dalam publikasi sehingga membuat perspektif masyarakat berkembang negatif. Omnibuslaw yang memantik Polemik Berapi menyebabkan hirup perdebatan dan aksi jalanan dilakukan masyarakat. Isu yang ditonjolkan adalah posedural lebih sering di bahas pada episode ini dibandingkan membahasa isi/substansi, kemudian penyelesaian masalah yang dilakukan adalah dengan menarik komitmen ketua Baleg untuk mendengar dan mempertimbangkan suara publik.

Program Mata Najwa pada episode "Mereka-Reka Cipta Kerja” di Trans7 menunjukan bahwa adanya keseimbangan dalam pemilihan narasumber antara yang pro dan kontra terhadap kebijakan Omnibuslaw, dari keleluasaan berbicara Mata Najwa juga tidak membatasi narasumber untuk berbicara dan talkshow tersebut dapat diakses secara terbuka di televisi maupun youtube kemudian untuk hasil dari diskusi tersebut juga dibagikan ke dalam kanal youtube NarasiTV dan Najwa Shihab. Tayangan program Mata Najwa Episode "Mereka-Reka Cipta 
P-ISSN 2580 - 7781

E-ISSN $2615-3238$

Kerja" Di Trans7 dapat menjadi sumber informasi yang akurat dan menerapkan prinsip jurnalisme independen atau tidak memihak dan sangat terbuka.

Pada zaman digital seperti saat ini, internet merupakan bagian yang tidak asing lagi dimasyarakat. Setiap kalangan mulai dari anak-anak sampai orangtua sudah mengenal media sosial dan Youtube untuk saling berinteraksi dan menerima informasi. Karena, semakin bebasnya setiap orang bisa berinteraksi dan berbagi informasi, maka masyarakat sebagai penerima informasi perlu memahami bahwa setiap informasi yang disampaikan merupakan sesuatu yang dikonstruksi. Untuk itu masyarakat harus cerdas dan tidak mudah terprovokasi dalam menerima setiap informasi.

\section{DAFTAR PUSTAKA}

Atmadja, Xena Levina. 2014. Analisis Framing Terhadap Pemberitaan Sosok Basuki Tjahaja Purnama (Ahok) Di Media Online. Jurnal EKomunikasi 2, 2(1).

Badri, M. 2017. “Jurnalisme Independen Vs Jurnalisme Partisan”. [Online]. Tersedia pada: http://ajikotamandar.or.id/2017/01/06/jurnalismeindependen-vs jurnalisme-partisan/.

Barratut, Taqiyyah Rafie. 2018. 'Program 'Mata Najwa' Nongol Lagi, Tapi Kini Pindah Ke Trans7". [Online]. Tersedia pada: https://www.tribunnews.com/seleb/2018/01/05/program-mata-najwanongol-lagi-tapi-kini-pindah-ke-trans7.

Biro Humas Hukum dan Kerjasama Kemenkum HAM. (Tanpa Tahun). RUU Omnibus Law Cipta Lapangan Kerja Untuk Tingkatkan Pertumbuhan Ekonomi. [Online]. Tersedia pada: https://www.kemenkumham.go.id/berita/ruu-omnibus-lawciptalapangan-kerja-untuk-tingkatkan-pertumbuhan-ekonomi

Denzin, Norman K. dan Yvonna S. Lincoln (eds.). 2009. Handbook of Qualitative Research. Terj. Dariyatno dkk. Jogjakarta: Pustaka Pelajar.

Eriyanto. 2002. Analisis Framing : Konstruksi, Ideologi, dan Politik Media. Yogyakarta : LKiS Yogyakarta.

F, Agus Setyawan. 2020. "DPR Jadwalkan 10 Kali Rapat RUU Ciptaker Hingga Paripurna,". [Online]. Tersedia pada: https://www.cnnindonesia.com/nasional/20200616172238-32513963/dpr-jadwalkan-10-kali-rapat-ruu-ciptaker-hingga-paripurna.

Fadhrotul, Vina. 2020. "Sederet Fakta Rapat Paripurna Pengesahan Omnibus Law UU Cipta Kerja, Dari Interupsi Hingga Walk-Out”. [Online]. Tersedia 
pada:https://www.kompas.com/tren/read/2020/10/06/144227465/sederetfakta-rapat-paripurna-pengesahan-omnibus-law-uu-cipta-kerjadari?page $=$ all.

Fey/nma/NMA. 2020. "Pelajar Ikut Demo Tolak UU Ciptaker Bersama Buruh \& Mahasiswa”. [Online]. Tersedia pada: https://www.cnnindonesia.com/nasional/20201116144136-20570371/pelajar-ikut-demo-tolak-uu-ciptaker-bersama-buruhmahasiswa.Prabowo,A. S.; Triputra, A. N.; \& Junaidi, Y. (2020). "Politik Hukum Omnibus Law Di Indonesia". Pamator Journal, 13(1), 1-6

Komisi Penyiaran and Indonesia. 2019. Kualitas Program Siaran Tv Periode Ii Tahun 2019. KPI.

Sani, Ahmad Faiz Ibnu. 2020. "Viral Puan Maharani Diduga Matikan Mikrofon Saat Politikus Demokrat Interupsi,”. [Online]. Tersedia pada: https://nasional.tempo.co/read/1393388/viral-puan-maharani-didugamatikan-mikrofon-saat-politikus-demokrat-interupsi/full\&view=ok.

Saragih, M. Y. 2018. "Media Massa dan Jurnalisme: Kajian Pemaknaan Antara Media Massa Cetak dan Jurnalistik". Jurnal Pemberdayaan Masyarakat. 6 (1), 87.

Sekretariat Presiden.2020. Pernyataan Presiden RI Penundaan Pembahasan Klaster Ketenagakerjaan RUU Cipta Kerja. [Online]. Tersedia pada: https://www.youtube.com/watch?v=AcuEbz9AJL0.

Waluyo, Djoko. 2018. "Makna Jurnalisme Dalam Era Digital: Suatu Peluang Transformasi". Diakom: Jurnal Media dan Komunikasi, 1 (1), 35. 